\title{
Immunohistochemical and hybridocytochemical study on ghrelin signalling in the rat seminiferous epithelium
}

\author{
Andrzej Lukaszyk ${ }^{1}$, Ludmila Rafińska ${ }^{1}$, Piotr Sawiński', Aldona Kasprzak ${ }^{1}$, \\ Karolina Olejniczak ${ }^{1}$, Marcin Ruciński ${ }^{1}$, Marek Ruchała ${ }^{2}$, Jerzy Sowiński²
}

\author{
${ }^{1}$ Department of Histology and Embryology and ${ }^{2}$ Department of Endocrinology, Metabolism and Internal \\ Medicine, Poznan University of Medical Sciences, Poznan, Poland
}

\begin{abstract}
The results of presented study demonstrate expression of ghrelin, its functional receptor GHSR-1a and their genes in spermatogenic cells of rat testis suggesting their functioning within seminiferous epithelium. The immunohistochemical and hybrydocytochemical expression, of proteins and transcripts, was estimated taking into account the cycle of seminiferous epithelium and phases of spermatogenesis. Both transcripts and ghrelin was found to show nuclear expression and scarcely cytoplasmic. Expression of genes for ghrelin and GHSR-1a was shown in early spermatocytes and round spermatids representing transcriptional phases of meiosis and spermiogenesis. Ghrelin was evidenced to show nuclear expression in two stage-specific windows, in late spermatogonia, in spermatocytes up to early pachytenes, and again in spermatids of acrosome and early maturation phase of spermiogenesis. In late pachytenes, secondary spermatocytes, round spermatids, maturing spermatids and spermatozoa the reaction is lacking. With two types of antibodies against the GHSR-1a used the two different patterns of immunostaining was evidenced suggesting two isoforms of GHSR-1a. The first evidenced GHSR1a in cytoplasm of spermatocytes, cell membrane and acrosomes of spermatids, Sertoli cell processes and heads of spermatozoa. With second type of antibodies the immunostaining marks all steps of evolution of acrosome in spermatids. It is believed that site of ghrelin expression in seminiferous epithelium may indicate its role in local regulations, not excepting the intracellular signalling. Immunostaining pattern for GHSR-1a seems to suggest both its participation in the cross-talk among the cells and also process of furnishing gametes with GHSR-1a for its response to ghrelin in seminal plasma or female reproductive tract.
\end{abstract}

Key words: ghrelin, GHSR-1a, rat seminiferous epithelium, germ cells, immunohistochemistry - hybridocytochemistry

\section{Introduction}

The process of the gamete production, spermatogenesis, is known as taking course in seminiferous epithelium under specific conditions provided by hormones, specific organization of the epithelium, its compartmentalisation and by composite local control system functioning as paracrine/autocrine/juxtacrine signalling among the stromal somatic cells and germ cell line. The hormones initiating and maintaining spermatogenesis, the role of FSH and testosterone, are generally known for many decades [1-3]. The local regulatory mechanism has been defined during last two decades and the list of its messengers, the local sig-

Correspondence: A. Łukaszyk, Department of Histology end Embryology, Poznań Univeristy of Medical Sciences,

Święcickiego 6, PL-60-781 Poznań, Poland;

tel.: (+4861) 8546455, fax.: (+4861) 8546440,

e-mail: anluk@ump.edu.pl nalling molecules, has been growing with years. The list includes growth factors, polypeptides of hormonal and paracrine nature, transcriptional modulators, interleukins and receptors of these molecules, all of them being the mediators in a cross talk between somatic and germ cells [4-17].

Some of the signalling molecules play essential role in the control of both the energy balance and reproduction by acting on more than one level of neuroendocrine axis as well as within local control of events in testis including the mechanism within seminiferous epithelium. An example of molecules acting in hypothalamus and testis is leptin, however, ghrelin has been recognized as functional antagonist of leptin [18-20]. Moreover, ghrelin has been found to exert antagonistic effects towards stem cell factor promoting cell proliferation. In testis ghrelin specifically inhibited the proliferative activity of immature Leydig cells by down-regulating the stem cell factor gene expression [21]. 
Ghrelin belonging, together with des-acyl ghrelin and obestatin, to the ghrelin gene derived products, has been recognized as peptide distributed widely in numerous cell populations and exerting multiple actions [22-26]. The circulating ghrelin has to be produced by stomach [27], however this is evident that ghrelin and its functional receptor (GHSR-1a) are synthesized in many organs often both within the same cells. Thus, target cells are expected to respond to both exogenous and endogenous ghrelin, the last being involved in local paracrine/autocrine regulatory mechanism modulating cell function including target cells in testis. In human and mammalian testis the gene expression for both ghrelin and GHSR-1a was evidenced [28] and the cells with ghrelin and GHSR-1a expression in testis were documented although physiological role of these proteins in seminiferous epithelium seems to need further elucidation [21,29-36].

In reason of a deficiency or controversies in evaluation of ghrelin and ghrelin receptor GHSR1a expression in the seminiferous epithelium in the presented study we focused attention on the problem in the adult rat testis using commercial antibodies and taking into account also site of their gene expression demonstrated by in situ hybridisation technique. With the results obtained we intend to take part in the discussion on the possible role of ghrelin and GHSR-1a as signalling molecules in local regulation of spermatogenesis.

\section{Materials and Methods}

Animal and chemicals. The animals used in this study were adult, 90-day-old, male Wistar rats which were kept under standard conditions of temperature $\left(21 \pm 2^{\circ} \mathrm{C}\right)$ and lighting $(14 \mathrm{~L} / 10 \mathrm{D})$, and had free access to food pellets and water. The protocol of the study and procedures was approved by Local Ethical Commission for Experimentation on Animals. The source of antibodies and other reagents is as follows: Agaroza Basila LE (Prona); access RT PCR System and SSC (Promega Corp., Madison, WI, USA); DNA ladder (Fermentas); diethyl pyrocarbonate (DEPC), ethidine bromide, formamide, ghrelin, isopropanol and pre-hybridisation solution (Sigma-Aldrich Corp., St. Louis, MO, USA); polyclonal rabbit anti-ghrelin antibody and polyclonal rabbit anti-GHSR-1A antibody (both from Phoenix Europe $\mathrm{GmbH}$, Karlsruhe, Germany); polyclonal rabbit anti-ghrelin receptor type 1A antibody (Millipore, USA); dextran polymer peroxidase labelled, 3-3'diaminobenzidine hydrochloride (DAB) (both from DakoCytomation); prime RNase Inhibitor, $7500 \mathrm{u}$ (Eppendorf); proteinase $\mathrm{K}$ (Dako); TRIS (AccuGene Maryland, USA); horse radish peroxidase and sheep anti-digoxygenin MAb conjugated with horseradish peroxidase (Roche, Mannheim, Germany); biotinylated tyramine (PerkinElmer Life Sciences, Inc., Boston, MA, USA); RNase A solution (R\&D Systems); streptavidin-biotin-peroxidase complex (LSAB2) (Dako). The primers were designed using Primer Selekt, DNAstar software. The primers and digoxygenin-labelled oligonucleotides were produced by the Institute of Biochemistry and Biophysics, Polish Academy of Sciences, Warszawa, Poland.

Collection and treatment of tissues. The male rats were sacrificed by decapitation. At autopsy testes were removed and secured for isolation of RNA (RT-PCR) or fixed in Bouin's fluid or 4\% paraformaldehyde and embedded in paraffin. The paraffin sections were used for (1) immunocytochemical demonstration of ghrelin and GHSR-1a receptor in seminiferous epithelium and (2) for expression of genes of ghrelin and its receptor by in situ hybridisation technique.

Immunohistochemistry. The $5 \mu \mathrm{m}$ thick sections mounted on SuperFrost/Plus microscope slides were deparaffinized and subjected to the detection procedure. The sections designated for the procedure with using peroxidase and diaminobenzidine were preincubated with $1 \% \mathrm{H}_{2} \mathrm{O}_{2}$ to inhibit endogenous peroxidase. Polyclonal rabbit anti-ghrelin and two different rabbit anti-GHSR1A antibodies (purchased in Phoenix-Pharmaceuticals and in Millipore) were used. The sections were treated with primary antibody at night at $4{ }^{\circ} \mathrm{C}$. After washing in phosphate-buffered saline (PBS) $3 \times 3 \mathrm{~min}$, the sections were incubated with the secondary biotinylated link anti-mouse and anti-rabbit $\operatorname{IgG}(20 \mathrm{~min})$ and with the streptavidin-biotin-peroxidase complex (LSAB2) (20 min). The studies followed the classical ABC technique [37]. The color reaction was evoked with $0.05 \%$ diaminobenzidine dissolved in $0.05 \mathrm{M}$ Tris- $\mathrm{HCl}$ buffer, $\mathrm{pH} 7.6$, supplemented with $0.001 \% \mathrm{H}_{2} \mathrm{O}_{2}$. Finally, the slides were counterstained with hematoxylin. Positive reaction manifested, in at least three sequential sections, as a dark brown or black precipitate in the cells. Moreover, also the procedure with using alkaline phosphatase instead peroxidase was applied to demonstrate the immunoreaction in the slides. For positive control an expression of the hormone in ghrelin cells of rat gastric mucosa was accepted and for the negative control IgG or complete rabbit serum were used instead antibodies.

Expression of genes for ghrelin and GHSR-1a. Expression of genes for ghrelin and its receptor in rat male gonads was demonstrated applying RT-PCR technique and also in formaldehyde fixed sections by in situ hybridisation technique.

RT-PCR. The procedure used with this technique was as follows. Total RNA was isolated from the testes using Chomczynski-Sacchi method. RNA was assayed in the samples spectrophotometrically. Reverse transcription was performed using $A M V$ reverse transcriptase (Avian Myeloblastosis Virus) and oligo-dT ${ }_{15}$ primer $(1 \mu \mathrm{g}$ of isolated RNA per reaction). The acquired cDNA was subjected to PCR reaction using thermostabile Taq polymerase and primers for the tested proteins (Table 1). Reaction was conducted in 34 cycles and reaction products analyzed on agarose gel. Conditions of the reaction were as follows: denaturation $94^{\circ} \mathrm{C}, 60 \mathrm{sec}$, anealing of primers $58^{\circ} \mathrm{C}, 30 \mathrm{sec}$., elongation of primers $72^{\circ} \mathrm{C}, 60 \mathrm{sec}$.

In situ hybridisation. Two digoxygenin-labelled oligoprobes specific for rat ghrelin (5'-TTA GCT GGC GCC TCT TTG ACC TCT TC-3') and rat ghrelin-receptor (5'-ACA CCA CCA CAG CAA GCA TCT TCA C-3') mRNA were used, detected with sheep antidigoxygenin MAb (Fab fragments), conjugated with HRP. In the hybridocytochemical studies, the classical ones and those amplified by the ImmunoMax technique, sequential sections of the tissue material were applied, which were pre-tested by immunocytochemical techniques. The in situ hybridisation protocol of R\&D Systems was employed with our own modification [38]. Subsequent stages involved paraffin removal from the section using xylene, ethanols and wash in DEPC-treated distilled water, each lasting 1-5 min, and washing in 0.05 M TRIS for $5 \mathrm{~min}$ in room temperature. Endogenous peroxidase was blocked by $15 \mathrm{~min}$ incubation of the section in $1 \% \mathrm{H}_{2} \mathrm{O}_{2}$. Then, the sections were digested with proteinase $\mathrm{K}, 200 \mu \mathrm{g} / \mathrm{ml}$ for $15 \mathrm{~min}$ at $37^{\circ} \mathrm{C}$. Subsequently, the sections were washed in $1 \times \mathrm{PBS}$ for $10 \mathrm{~min}$ at RT, fixed again in $0.4 \%$ formaldehyde at $4^{\circ} \mathrm{C}$ for $15 \mathrm{~min}$. Next the slides were washed in DEPC-distilled water for $1 \mathrm{~min}$ each. The pre-hybridisation solution was applied under a cover slip and the preparation 
Table 1. Oligo-primer pairs used for RT-PCR amplification of ghrelin and receptor GHSR-1a (RNA isolated from testes of 90-day-old male rats). The PCR cycles for each of cases were 34 )

\begin{tabular}{|c|c|c|c|c|c|}
\hline cDNA & $\begin{array}{l}\text { Access number } \\
\text { to Genbank }\end{array}$ & l'rimer & Sequence of primer $\left(5^{\prime}-3^{\prime}\right)$ & l'osition & $\begin{array}{c}\text { l'CR } \\
\text { product } \\
\text { size (bp) }\end{array}$ \\
\hline Ghrelin (rat) & NM 021669 & $\begin{array}{l}\mathrm{S} \\
\mathrm{A}\end{array}$ & $\begin{array}{l}\text { CCAGCAGAGAAAGGAATCCAAG } \\
\text { AACATCGAAGGGACATTAAC }\end{array}$ & $\begin{array}{l}135-156 \\
255-276\end{array}$ & 142 \\
\hline GhsR-1a (rat) & NM 032075 & $\begin{array}{l}\mathrm{S} \\
\mathrm{A}\end{array}$ & $\begin{array}{c}\text { AGTCTCATCGGGAGGAAGCTATG } \\
\text { ACACTGCCACCCGGIACTICT }\end{array}$ & $\begin{array}{l}694-716 \\
977-997\end{array}$ & 304 \\
\hline
\end{tabular}

was incubated for $1 \mathrm{~h}$ at $37^{\circ} \mathrm{C}$. Various concentrations of the oligoprobe were tested, ranging from 500 to $1000 \mathrm{ng} / \mathrm{ml}$ (the best result was obtained using $600 \mathrm{ng} / \mathrm{ml}$ concentration of the oligoprobes), dissolved in the prehybridisation solution plus $50 \%$ formamide. The proper hybridisation took place overnight ( 16 to $18 \mathrm{~h}$ ) at $38^{\circ} \mathrm{C}$, under a coverslip, in a humid chamber. After removing of the coverslips, the sections were washed in decreasing concentrations of $\mathrm{SSC}$ plus $50 \%$ formamide at $37^{\circ} \mathrm{C}$ and, then, in $0.1 \mathrm{M}$ Tris- $\mathrm{HCl}, \mathrm{pH}$ 7.6 and $0.1 \%$ Triton X-100 in TBS for $15 \mathrm{~min}$ at room temperature. Sheep anti-digoxygenin MAb conjugated with HRP was applied for $1 \mathrm{~h}$ at room temperature in dilution 1:30. After a wash in PBS, the hybrids were detected using $0.05 \% \mathrm{DAB}$ in $0.05 \mathrm{M}$ Tris $/ \mathrm{HCl}$, $\mathrm{pH} 7.6$ supplemented with $0.001 \% \mathrm{H}_{2} \mathrm{O}_{2}$, for 5 min.

In case of ImmunoMax technique [39] after the incubation with anti-digoxygenin MAbs and a wash in PBS/Tween20, the biotinylated tyramine was applied at 1:50 dilution for $3 \mathrm{~min}$ at room temperature. The streptavidin-peroxidase complex was added for $30 \mathrm{~min}$. The hybrids were detected using $0.05 \% \mathrm{DAB}$ in $0.05 \mathrm{M}$ Tris/HCl, pH 7.6 supplemented with $0.001 \% \mathrm{H}_{2} \mathrm{O}_{2}$, for 5 min at room temperature. Some preparations were counterstained with hematoxylin. Negative controls included (a) hybridisation without addition of the oligoprobe and (b) incubations of slides in an RNase A solution, $20 \mathrm{mg} / \mathrm{ml}$ in $2 \times \mathrm{SSC} / 10 \mathrm{mM} \mathrm{MgCl}$, $\mathrm{pH} 8.0$ for $30 \mathrm{~min}$ at room temperature, before hybridisation. For verification in each case the procedure was repeated at least twice.

\section{Results}

\section{Immunohistochemical expression of ghrelin and its functional receptor GHSR-1a}

With using anti-ghrelin antibodies (Phoenix-Pharmacuticals), peroxidase-labelled dextran polymer and diaminobenzidine as chromogen or the procedure with alkaline phosphatase as reaction marker the expression of ghrelin could be demonstrated, apart from interstitial Ledig cells, in the nuclei of some spermatogonia, leptotene, zygotene and early pachytene spermatocytes and in spermatids of acrosome and early maturation phase of spermiogenesis. In Fig. 1A the reaction marks nuclei of zygotenes (arrows) and 13 step spermatids (black arrow heads) in XII stage of seminiferous epithelium cycle and also in early pachytenes (open arrow head). The effects of the procedure with alkaline phosphatase application (Fig. 1B) confirm ghrelin localization seen in Fig. 1A showing that in X/IX stages of the cycle the expression of ghrelin is marked in nuclei of leptotenes and 10/11 step spermatids. No reaction is seen in pachytene nuclei. No reaction product is seen in the slides treated as negative control (Fig. 1C). Fig. 1D verifies positively the applied procedure demonstrating immunostaining of ghrelin in X/A-like cells of the rat stomach which are the classic ghrelin secreting cells.

Expression of ghrelin receptor (GHSR-1a) could be documented with two kinds of the antibodies used. Those produced by Phoenix-Pharmaceuticals bound to epitopes in Leydig cells and in various cells of the seminiferous epithelium. As it is seen in Figs. $2 \mathrm{~A}$ and $\mathrm{D}$, beside the interstitial Leydig cells, in the seminiferous epithelium (fragments representing VII, VIII and IX stages of the cycle) the immunoreaction product is localized in cytoplasm of preleptotenes and pachytenes, in cell membranes and acrosomes of spermatids steps $7-9$ and on heads of step 19 spermatids being prior or in the course of spermiation. Moreover, also the processes of stromal Sertoli cells show immunostaining. Slides treated with rat IgG instead first antibody show no reaction (Fig. 2C). With Milipore antibodies the expression of probably an isoform of GHSR-1a could be documented characteristically in spermatids of all steps of spermiogenesis marking the Golgi, caps and acrosomes of round spermatids and heads of maturation phase spermatids. Fig. 2B demonstrates the immunostaining specifically in acrosomes of spermatids step 8 and heads of spermatids steps 12/14 and 19. The expression of both isoforms of GHSR-1a in rat seminiferous epithelium is summarized jointly in diagram (Fig. 3) that indicate clearly the equipment of germinal cells in GHSR-1a receptor to interact with the local ghrelin signals, and also the equipment of matured spermatids released as spermatozoa presumably for responding to ghrelin in seminal plasma or female reproductive tract fluid.

\section{Expression of genes for ghrelin and GHSR1a}

Electrophoretic analysis of RT-PCR products with primers specific to rat ghrelin and GHSR-1a receptor (Table 1) indicates expression of genes for the two proteins in the adult rat testis (Fig. $1 \mathrm{~F}$ and $2 \mathrm{~F}$, respectively). Conventional RT-PCR allowed to detect specific mRNA of the ghrelin and GHSR-1a genes in the rat testis. The product of reaction has expected size and there is no product seen in the negative control (-RT) samples. 

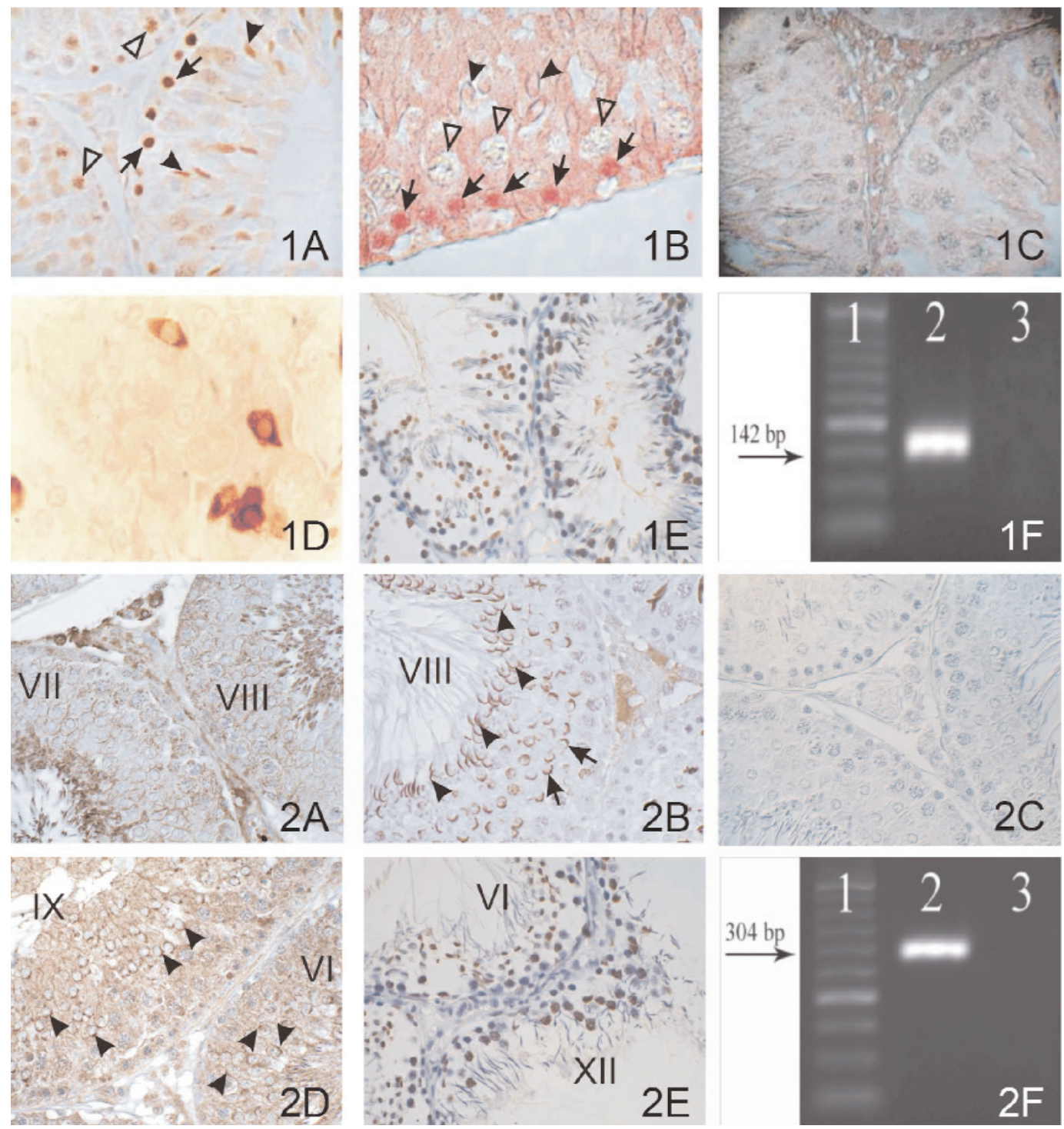

Fig. 1. A: Immunohistochemical demonstration of ghrelin in rat germinal epithelium with anti-ghrelin antibodies (Phoenix-Pharmacuticals), peroxidase-labelled dextran polymer and diaminobenzidine as chromogen. The reaction marks nuclei of zygotenes (arrows) and 13 step spermatids (black arrow heads) in XII stage of seminiferous epithelium cycle and also in early pachytenes (open arrow heads). B: Demonstration of ghrelin in rat seminiferous epithelium with anti-ghrelin antibodies (Phoenix-Pharmaceuticals) and alkaline phosphatase as reaction marker. Positive reaction confirms ghrelin localization shown, in fig. 1a. In X/IX stages of the cycle the expression of ghrelin is marked in nuclei of leptotenes (arrows) and 10/11 step spermatids (black arrow heads). No reaction is seen in pachytene nuclei (open arrow heads). C: Control reaction with use of normal rabbit IgG instead of anti-ghrelin antibodies and alkaline phosphatase as reaction marker. No reaction in leptotenes and pachytenes. D: Positive control. Ghrelin expression in X/A-like cells of the rat stomach demonstrated immunohistochemically using antighrelin antibodies (Phoenix-Pharmaceuticals) and peroxidase-labelled dextran polymer and diaminobenzidine as chromogen. E: Ghrelin gene expression in rat testis demonstrated by in situ hybridisation technique. The reaction marks ghrelin transcripts in the cell nulei of pachytene spematocytes and round spermatids. No reaction in nuclei of elongating spermatids. F: Electrophoretic analysis of RT-PCR products with primers specific for rat ghrelin. RNA was isolated from 90-day-old rat testis. 1 - DNA size marker, 2 - RT-PCR product with primers and 3 control reaction (-RT). Fig. 2. (A - D): Ghrelin receptor (GHSR-1a) expression in the rat testis demonstrated immunohistochemically using anti-GHSR-1a polyclonal antibodies of two different types. A and D: Immunoreaction using antibodies from Phoenix-Pharmaceuticals marks Leydig cell cytoplasm, and in the seminiferous epithelium (VII and VIII stage of the cycle of s. e.) it marks heads of late spermatids and cell membranes of round spermatids; less intensively it marks acrosomes and cytoplasmic structures of spermatogenic cells (A); in stages IX and VI the immunostaining marks acrosomes (D). B: With antibodies from Millipore, using classic ABC technique with microwave oven pretreatment, the reaction, in stage VIII of cycle (left), marks spermatids (acrosomes) in 8 (arrows) and 19 (arrow heads) steps of spermiogenesis and in other stages (right) it marks heads of maturing spermatids; less intensely the reaction marks Leydig cells. C: Control reaction with use of normal rabbit IgG instead of anti-ghrelin antibodies. No reaction in leptotenes, pachytenes and heads (acrosomes) of spermatids. E: GHSR gene expression in seminiferous epithelium of the rat demonstrated by in situ hybridisation technique. The reaction intensively marks nuclei of spermatocytes and round spermatids. In heads of elongating spermatids, up to 19 step of spermiogenesis, the reaction is lacking. F: Electrophoretic analysis of RT-PCR products with primers specific for rat ghrelin receptor GHSR-1a. RNA was isolated from 90-day-old rat testis. 1 - DNA size marker, 2 - RT-PCR product with primers, for GHSR-1a and 3 - control reaction (-RT). 


\begin{tabular}{|c|c|c|c|c|c|c|c|c|c|c|c|c|c|}
\hline 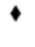 & $\bullet$ & 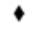 & $\bullet$ & + & & & & & & & & & \\
\hline 15 & 16 & 17 & 18 & 19 & & & & & & & & & \\
\hline : & : & : & $\dot{0}$ & : & $:$ & : & : & " & " & . & • & • & • \\
\hline 1 & 2 & 3 & 4 & 5 & 6 & 7 & 8 & 9 & 10 & 11 & 12 & 13 & 14 \\
\hline $\begin{array}{l}: \\
\\
\end{array}$ & $\begin{array}{l}: \\
: \\
\end{array}$ & $\begin{array}{l}: \\
: \\
\end{array}$ & $\begin{array}{l}: \\
: \\
\\
\end{array}$ & : & : & $\begin{array}{l}\dot{0} \\
\dot{P}\end{array}$ & $\begin{array}{l}: \\
0 \\
P\end{array}$ & $\begin{array}{l}: \\
: \\
\text { p }\end{array}$ & $\begin{array}{l}\dot{0} \\
\dot{P} \\
P\end{array}$ & $\begin{array}{l}: \\
\vdots \\
P\end{array}$ & $\begin{array}{l}\dot{0} \\
\dot{P}\end{array}$ & $\begin{array}{l}\dot{\vdots} \\
\text { Di }\end{array}$ & $\begin{array}{l}\dot{0} \\
\vdots \\
\text { II }\end{array}$ \\
\hline $\begin{array}{l}\vdots \\
\text { In }\end{array}$ & $\begin{array}{l}: \\
\vdots \\
\text { In }\end{array}$ & $\begin{array}{l}: \\
\vdots \\
\text { In }\end{array}$ & $\begin{array}{l}: \\
\vdots \\
\mathrm{In}^{\mathrm{m}}\end{array}$ & : & $\begin{array}{l}: \\
: \\
\text { в }\end{array}$ & $\begin{array}{l}: \\
: \\
{ }_{\mathrm{pL}}\end{array}$ & $\begin{array}{l}: \\
\vdots \\
\mathrm{pL}\end{array}$ & : & $:$ & $:$ & $\begin{array}{l}: \\
\vdots \\
\mathrm{z}\end{array}$ & $\begin{array}{l}: \\
\mathrm{z}\end{array}$ & $\begin{array}{l}: \\
\vdots \\
\mathrm{z}\end{array}$ \\
\hline A & $A$ & $\mathbf{A}$ & $A$ & A & $A$ & $\mathbf{A}$ & A & $\mathbf{A}^{\mathrm{m}}$ & A & $A$ & $A^{\prime \prime}$ & $\mathbf{A}$ & $A^{m}$ \\
\hline I & II & III & IV & $\mathbf{v}$ & VI & VII & VIII & $\mathbf{I X}$ & $x$ & XI & XII & XIII & XIV \\
\hline
\end{tabular}

Fig. 3. Expression of ghrelin, ghrelin receptor (GHSR-1a) and their transcripts (mRNA) in different stage-dependent windows of spermatogenesis. The diagram shows arrangement of spermatogenetic cells to compose 14 stages of cycle of seminiferous epithelium (according to the classification of Leblond and Clermont [4042] and occurrence of protein or transcript in the cells are marked as follows: expression of ghrelin ( $\boldsymbol{\square})$ and receptor GHSR-1a ( $\bullet$ ), gene expression (mRNA) for ghrelin (•) and for GHSR-1a (o). Abbreviations: A, spermatogonia of type $\mathrm{A} ; \mathrm{A}^{\mathrm{m}}$, mitotic division of type A spermatogonia; In, intermediate type of spermatogonia; B, type B spermatogonia; $\mathrm{pL}, \mathrm{L}, \mathrm{Z}, \mathrm{P}$ and $\mathrm{Di}$, primary spermatocytes, respectively, at preleptotene, leptotene, zygotene, pachytene and diplotene step of the meiotic division; II, secondary spermatocyte; 119 , spermatids at 1-19 step of spermiogenesis; I - XIV, numbers of consecutive 14 stages of cycle of the rat seminiferous epithelium.

With in situ hybridisation technique the expression of genes for ghrelin and GHSR within seminiferous epithelium was found in germ cells of transcriptional phases of spermatogenesis. Fig. 1 E shows reaction marking ghrelin transcripts in the cell nulei of pachytene spematocytes and round spermatids while no reaction is seen in nuclei of elongating spermatids. Fig. 2 E demonstrates the transcripts of the GHSR gene expression. The hybridocytochemical reaction intensively marks nuclei of spermatocytes and round spermatids. However, in heads of elongating, maturation phase spermatids, up to 19 step of spermiogenesis, the reaction is lacking.

\section{Stage-specificity of the molecule expression}

A correlation of the expression of ghrelin, GHSR-1a and their genes in gametogenic cells with cycle of the rat seminiferous epithelium, presented in fig. 3, illus- trates the cells marked in particular stages of the cycle. The diagram demonstrates cellular composition of each of 14 stages of the cycle (arranged vertically) in which gametogenic cells showing the protein or transcript expression are marked. While read horizontally the diagram imagines the progress in spermatogenesis. As it is presented the genes for ghrelin and GHSR-1a are expressed in late proliferation phase of spermatogenesis, during meiosis and transcriptional phase of spermiogenesis. Ghrelin is expressed during two stage-specific windows of spermatogenesis, i.e. in late spermatogonia and primary spermatocytes up to early pachytenes, and in spermatids in acrosome and early maturation phases of spermiogenesis, while GHSR-1a receptor, its two isoforms jointly, is expressed in late spermatogonia, spermatocytes and spermatids up to the step of spermiation.

\section{Discussion}

Since identification of ghrelin as natural ligand for GH secretagogue receptor by Kojima and coworkers in 1999 [22] the searching for its expression in the testis was focused primarily on Leydig cells. A testis-specific and developmentally-induced ghrelin gene-derived transcript has been reported [29]. Tena-Sempere and co-workers [33] provided evidences for expression of both ghrelin and its functional receptor in the male gonad by demonstrating gene expression throughout extrauterine development of rat testis and its disappearing in experiments in which Leydig cells were selectively destroyed. They documented ghrelin in Leydig cells immunohistochemically and found inhibitory effects of ghrelin on stimulated secretion of testosterone in vitro by demonstrating a decrease in levels of CG-stimulated production of mRNAs for synthesis of StAR protein, $\mathrm{P}_{450}$ cleavage enzyme and two steroid dehydrogenases. In human testis the same research team [34] had evidenced expression of genes for ghrelin and its receptor, as well as they demonstrated the protein immunohistochemically in Leydig and Sertoli cells but they did not detect ghrelin in germinal cells at any step of spermatogenesis. In human spermatogenic cells, especially in pachytenes, they localized GHSR-1a protein. Controversially, other researchers demonstrated ghrelin immunohistochemically in pachytene spermatocytes of human [36] and ovine testis [43].

Spermatocytes in human, rat and ovine testis expressed ghrelin and GHSR-1a and authors suggested that ghrelin can influence spermatogenesis acting via Leydig cells and may operate as a local regulator in the fine-tuning of spermatogenic function [36], however, without exception of the possibility that ghrelin may regulate gene expression of local modulators in the rat seminiferous tubules $[32,34]$. 
Appreciating the above novel data reflecting role of the peptide and its receptor in control of male gonad function via Leydig cells we intend to consider the gathered results of own studies in light of the local regulatory mechanism for the course of spermatogenesis within the cycle of seminiferous epithelium. The results discussed in the presented paper indicate a stage-specificity in expression of ghrelin and GHSR1a receptor in seminiferous epithelium of adult rat suggesting their indispensability for consecutive step(s) of spermatogenesis to proceed and to furnish male gametes for fertilization. Expression of genes for ghrelin and the ghrelin receptor GHSR1a shows a convergence as to localization of transcripts. Demonstration of transcripts for ghrelin in pachytenes and round spermatids, with in situ hybridization technique, seems to make evidences verifying the expression of ghrelin in germinal cells despite the literature data that in germ cell line this peptide is lacking $[30,34]$.

Another facet of the matter is intranuclear localization of ghrelin and its transcripts in spermatocytes and spermatids. Intranuclear expression of transcripts seems to reflect site of hybridization of the primer projected and used. However, the presence of ghrelin protein explicitly repeatable in nuclei of gametogenic cells being on specific steps of spermatogenesis may suggest its particular role as signalling molecule in the intracellular regulation, especially that the nuclear localization of reaction product was confirmed in two procedures, with using peroxidase and alkaline phosphatase. Nuclear expression of ghrelin in gonads has been documented immunohistochemically also by other authors in testis [36,43] and ovary [44]. There are convincing evidences for intracellular processing of proteins and translocation the processed molecules to the nucleus to function as transcriptional regulators [45]. The results presented in this paper could suggest a role of ghrelin in transcriptional regulation of prophase of meiotic divisions and acrosome phase of spermiogenesis.

A next problem that needs to be discussed are two different patterns of localization of immunohistochemical reaction for the ghrelin receptor, GHSR-1a, in seminiferous epithelium, in dependence on antibodies applied, i.e. in almost all types of germ cells including cell membrane of round spermatids, heads of matured spermatids, and spermatozoa, and processes of Sertoli cells or the pattern, when Milipore antibodies were used, limited selectively to Golgi, acrosomes of spermatids and heads of matured spermatids and spermatozoa. The differences are suggestive enough to think that they represent two isoforms of GHSR-1a. The first of the patterns suggests the receptors responding to ghrelin available within seminiferous epithelium and being an element of local regulatory mechanism for spermatogenesis. The second pattern marking sper- matids may demonstrate the process of furnishing gametes with receptor being utilized after spermiation and as well after ejaculation. As to the first pattern the question is how the ghrelin is available in this epithelium if our results presented here indicates stage-specific intranuclear expression of ghrelin in germ cells only. However, in this reason the interstitial cells should be also included into sources of ghrelin for germinal epithelium. Ghrelin most likely passes bloodtestis barrier since this peptide has been evidenced as a molecule crossing the membrane barriers in CNS [46]. Moreover, ghrelin receptor may signal with $50 \%$ of maximal activity even in absence of its ligand [47].

Expression of ghrelin, ghrelin functional receptor and their transcripts in the rat germinal epithelium point out spermatogenic cells, apart from Leydig cells, as site of their synthesis and action. Expression of genes for ghrelin and its receptor GHSR-1a occurs in transcriptional phase of meiosis and spermiogenesis and mRNA succeeds to be demonstrated with in situ hybridisation technique in early spermatocytes and round spermatids showing nuclear and poorly cytoplasmic localization. Expression of ghrelin protein demonstrated immunohistochemically in spermatogenic cells is manifested in two stage-specific windows of spermatogenesis: (1) in the late phase of spermatogonia proliferation up to early phase of meiotic division and (2) during the acrosome and early maturation phase of spermiogenesis, showing nuclear localization. With the two types of antibodies used the expression of probably two isoforms of GHSR-1a could be demonstrated immunohistochemically, i.e. as receptor protein present in pachytene cytoplasm, cell membrane of round spermatids, heads of matured spermatids and processes of Sertoli cells and, when the second type of antibodies were used, as an isoform limited to spermatids of steps $1-19$ in which the reaction marked acrosome in the course of its differentiation and head of spermatids being released as spermatozoa. Expression of GHSR-1a on heads of matured spermatids could be documented with using both types of the antibodies. In turn, in relation to localization of ghrelin protein we believe that nuclear expression of ghrelin selectively in two phases of spermatogenesis indicates its involvement in intracellular signalling. Surprisingly, in comparable phases of spermatogenesis transcription of c-kit transmembrane tyrosine-kinase receptor is ceased (meiosis) and shorter c-kit transcripts that should encode a truncated isoform of the receptor protein are expressed in spertmatids steps $9-$ 13 [48]. Stem cell factor c-kit ligand is expressed at the level of spermatogonia and its role in germ cell development has been recognized as survival factor for primordial germ cells, spermatogonial stem cell niche and factor inducing proliferation of spermatogonia [49-52]. The stage-specific expression was found for a 
number of molecules acting as messengers of local regulatory mechanism within seminiferous epithelium. Pituitary adenylate cyclase-activating polypeptide (PACAP) is most intensely expressed in spermatids steps $3-12$ but not in maturation phase spermatids, its receptor in spermatids step $7-12$, and expression of the PACAP gene occurs in spermatogonia and primary spermatocytes $[14,15]$. Stage-specific expression was recognized also for other molecules as for IGF-I, activin, inhibin, NGF $\beta$, transcriptional factors, interleukins $[4-6,8,10,11]$. We also believe that expression of GHSR-1a isoforms illustrates conditions for a response of spermatogenic cells to ghrelin whithin the seminiferous epithelium and the process in which spermatozoa are furnished receiving receptor to respond, for instance, to seminal plasma ghrelin or to the ghrelin of female reproductive tract fluid available in the course of movement and capacitation of spermatozoa or acrosome reaction and fertilization. Ghrelin was found to occur in seminal plasma [53] and is present in uterine fluid [54].

Finally, it seems intriguing to discuss the presented results also with regard to potential mutations in ghrelin and/or its receptor since some data related to the ghrelin receptor mutations have been reported $[55,56]$. An animal model of reproductive defects that helps to recognize genes or mechanisms involved in pathophysiology of testis and fertility comprises a register of about 400 cases of infertility, subfertility, delayed fertility in one or both sexes $[57,58]$. The register includes mutation in a number of modulators of gonadal function, among others in c-kit ligand and leptin and their receptors, as cause of infertility in both sexes. Matzuk and Lamb [57,58] did not register mutations in ghrelin and its receptor proteins as a cause of idiopathic infertility. However, it has been proposed on the basis of comparison of the biological actions of leptin and ghrelin at different levels of the hypothalamic-pituitary-gonadal axis that, through concurrent or antagonistic actions, the ghrelin, when acting with leptin, may operate also as modulator of different reproductive functions [20]. In mice a lack of ghrelin does not affect fertility. While mice lacking ghrelin are fertile the mice lacking functional leptin (ob/ob) or with mutation of leptin receptor are obese, infertile, and exhibit impaired spermatogenesis [59-63]. In turn, experimental hyperghrelinemia in prepubertal male rats decreased serum LH and testosterone concentration and delayed timing of puberty [64]. Moreover, an overexpression of ghrelin gene resulting in high level of ghrelin was reported for Willi-Prader syndrome with combined impairment of LH secretion, LH stimulated testosterone production and local, presumably, primary defects in Sertoli and gametogenic cell line maturation [65-67].
In concluding remarks it seems to be acceptable that there is more than one point of ghrelin signaling in seminiferous epithelium: (1) in the local regulation of germ cell maturation most likely by cooperating with other regulatory molecules as c-kit ligands and leptin or exerting opposite action to them, (2) in intracellular signalling and, lastly, in (3) in influencing gametes since in the course of spermiogenesis the male gametes become equipped in the ghrelin receptor presumably to respond to ghrelin within the female reproductive tracts.

Acknowledgements: The research was supported by a grant 3951/P01/2006/31 from Ministry of Science and Higher Education, Poland.

\section{References}

[1] Steinberger E. Hormonal regulation of the seminiferous tubule function. In Hormonal Regulation of Spermatogenesis. F.S. French, V. Hansdson and E.M. Ritzen. [Eds], New York: Plenum Press, 1975;337-349.

[ 2] Steinberger E. Hormonal control of mammalian spermatogenesis. Physiol Rev. 2005;51:1-22.

[3] Tapanainen JS, Tilly JL, Vihko KK, Hsueh AJ. Hormonal control of apoptotic cell death in the testis: gonadotropins and androgens as testicular cell survival factors. Molecular Endocrinology 1993; 7:643-650.

[ 4] Parvinem M, Soder O, Mali P, Froysa B, Ritzen EM. In vitro stimulation of stage-specific deoxiribonucleic acid sythesis in rat seminiferous tubule segments by interleukin- $1 \alpha$. Endocrinology 1991;120:1614-1620.

[ 5] Parvinem M, Pelto-Huikko M, Soder O, Schultz R, Kaipia A, Mali P, Toppari J, Hakowirta H, Lonnenberg P, Ritzen EM, Ebendal T, Olson L, Hokfelt T, Person H. Expression of $\beta$-nerve growth factor and its receptor in rat seminiferous epithelium: specific function at the onset of meiosis. $J$ Cell Biol. 1992;117:629-641.

[ 6] Skinner MK. Cell-cell interactions in the testis. Endocrine Rev. 1991;12:45-77.

[ 7] Skinner MK. Secretion of growth factors and other regulatory factors. In The Sertoli Cell, L.D. Russel and M.D. Griswold [Eds], Clearwater FL: Cache River Press, 1993, pp. 237-247.

[ 8] Soder A, Syed V, Callard GV, Toppari J, Pollanen P, Parvinem M, Froysa B, Ritzen EM. Production and secretion of an interleukin-1-like factor is stage-dependent and correlates with spermatogonial DNA synthesis in rat seminiferous epithelium. Intern J Andrology, 1991;14:223-231.

[ 9] Yoshinaga K, Nishikawa S, Ogawa M. Role of c-kit in mouse spermatogenesis: identification of spermatogonia as a specific site of c-kit expression and function. Development. 1991;113:689-699.

[10] Kaipia A, Pentilla TL, Shimasaki S, Ling N, Parvinem M. Toppari J. Expression of inhibin $\beta \mathrm{A}$ and $\beta \mathrm{B}$, follistatin and activin A receptor messenger ribonucleic acid in rat seminiferous epithelium. Endocrinology 1992;131:2703-2710.

[11] Kaipia A, Parvinem M, Toppari J. Localization of activin receptor (ActR-IIB) mRNA in rat seminiferous epithelium. Endocrinology. 1993;132:477-479.

[12] Parvinem M. Cyclic function of Sertoli cells. In The Sertoli Cell, L.D. Russel and M.D. Griswold [Eds], Clearwater FL: Cache River Press, 1993, pp. 331-347.

[13] Steinberger A, Jakubowiak A. Sertoli cel culture: historical perspective and review of methods. In The Sertoli Cell, L.D Russel and M.D. Griswold [Eds], Clearwater FL: Cache River Press, 1993, pp. 155-179. 
[14] Shioda S, Legradi D, Leung WC, Nakajo S, Nakaja A, Arimura A. Localization of pituitary adenylate cyclase-activating polypeptide (PACAP) and its messenger ribonucleic acid in rat testis by light and electron microscopic immunocytochemistry and in situ hybridization. Endocrinology. 1994; 135:818-825

[15] Arimura A, Shioda S. Pituitary adenylate cyclase activating polypeptide (PACAP) and its receptors: neuroendocrine and endocrine interaction. Frontiers in Neuroendocrin. 1995;16: 53-88.

[16] Łukaszyk A. Application of the cell and molecular biology techniques in evaluation of the local mechanisms controlling spermatogenesis. Folia Histochem Cytobiol. 1996;34(suppl): 75-76.

[17] Sofikitis N, Pappas E, Kawatani A, Baltogiannis D, Loutradis D, Kanakas N, Giannakis D, Dimitriadis F, Tsoukanelis K, Georgiou I, Makrydimas G, Mio Y, Tarlatzis V, Melekos M, Miyagawa I. Efforts to create an artificial testis: culture systems of male germ cells under biochemical conditions resembling the seminiferous tubular biochemical environment. Human Reproduction Update. 2005;11:229-259.

[18] El-Hefnawy T, Ioffe S, Dym M. Expression of leptin receptor during germ cell development in the mouse testis. Endocrinology. 2000;141:2624-2630.

[19] Smith RG, Jiang H, Sun Y. Developments in ghrelin biology and potential clinical relevance. Trends Endocrinol and MeTable. 2005;16:436-442.

[20] Tena-Sempere M. Roles of ghrelin and leptin in the control of reproductive function Neuroendocrinol. 2007;86:229-241.

[21] Barreiro ML, Gaytan F, Castellano JM, Suominen JS, Roa M, Gaytan E, Aguilar E, Dieguez C, Toppari J, Tena-Sempere M. Ghrelin inhibits the proliferative activity of immature Leydig cells in vivo and regulates stem cell factor mRNA expression in rat testis. Endocrinology. 2004;145:4825-4834.

[22] Kojima M, Hosoda H, Date Y, Nakazato M, Matsuo H. Kangawa K. Ghrelin is a growth-hormone-releasing acylated peptide from stomach. Nature. 1999;402:856-660.

[23] Korbonits M, Goldstone AP, Gueorguiev M, Grossman AB. Ghrelin - a hormone with multiple functions. Frontiers in Neuroendocrinol. 2004;25:27-68.

[24] Lely AJ, Tschop M, Heiman ML, Ghigo E. Biological, physiological, pathophysiological and pharmacological aspects of ghrelin. Endocrine Rev. 2004;25:426-457.

[25] Kojima M, Kangawa K. Ghrelin: structure and function. Physiol Rev. 2005;85:495-522.

[26] Soares J-B, Leite-Moreira AF. Ghrelin, des-acyl ghrelin and obestatin: Three pieces of the same puzzle. Peptides 2008;29: 1255-1270.

[27] Date Y, Kojima M, Hosoda H, Sawaguchi A, Mondal MS, Suganuma T, Matsukura S, Kangawa K, Nakazato M. Ghrelin, a novel growth hormone-releasing acylated peptide, is synthesized in a distinct endocrine cell type in the gastrointestinal tracts of rats and humans. Endocrinology 2000;141: 4255-4261.

[28] Gnanapavan S, Kola B, Bustin SA, Morris DG McGee P, Fairclough P, Bhattacharya S, Carpenter R, Grossman AB, Korbonits $\mathrm{M}$. The tissue distribution of the mRNA of ghrelin and subtypes of its receptor, GHS-R, in humans. Clin Endocrinol MeTable 2002;87:2988-2991.

[29] Tanaka M, Hayashida Y, Nakao N, Nakai N, Nakashima K. Testis-specific and developmentally induced expression of a Ghrelin gene-derived transcript that encodes a novel polypeptide in the mouse. Biochem Biophys Acta. 2001;522:62-65.

[30] Barreiro ML, Gaytan F, Caminos JE, Pinilla L, Casanueva FF, Aguilar E, Dieguez C, Tena-Sempere M. Cellular location and hormonal regulation of ghrelin expression in rat testis. Biol Reprod. 2002;67:1768-1776.

[31] Barreiro ML, Suominen JS, Gaytan F, Pinilla L, Chopin LK, Casanueva FF, Dieguez C, Aguilar E, Toppari J, Tena-Sem- pere M. Developmental, stage-specific, and hormonally regulated expression of growth hormone secretagogue receptor messenger RNA in rat testis. Biol Reprod. 2003; 68:1631-1640.

[32] Barreiro ML, Tena-Sempere M. Ghrelin and reproduction: a novel signal linking energy status and fertility? Mol Cell Endocrinol. 2004;226:1-9.

[33] Tena-Sempere M, Barreiro ML, Gonzales F, Gaytan F, Zhang F, Caminos JE, Pinilla L, Casanueva FF, Dieguez C, Aguilar E. Novel expression and functional role of ghrelin in rat testis. Endocrinology 2002;143:717-725.

[34] Gaytan F, Barreiro ML, Caminos JE, Chopin LK, Herington AC, Morales C, Pinilla L, Paniagua R, Nistal M, Casanueva FF, Aguilar E, Dieguez C, Tena-Sempere M. Expression of ghrelin and its functional receptor, the type 1a growth hormone secretagogue receptor, in normal human testis and testicular tumors. J Clin Endocrinol MeTable. 2004;89:400-409.

[35] Garcia MC, JM, Lopez M, Alvarez CV, Casanueva F, TenaSempere M, Dieguez C. Role of ghrelin in reproduction. Reproduction. 2007;133:531-540.

[36] Ishikawa T, Fujioka H, Ishimura T, Takenska A, Fujisawa M. Ghrelin expression in human testis and serum testosterone level. J Androl. 2007;28:320-324.

[37] Hsu SM, Raine L, Fanger H. Use of avidin-biotin-peroxidase complex $(\mathrm{ABC})$ in immunoperoxidase techniques. $J$ Histochem Cytochem. 1981;29:577-580

[38] Kasprzak A, Zabel M, Biczysko W, Wysocki J, Adamek A, Spachacz R, Surdyk-Zasada J. Expression of cytokines (TNF- $\alpha$, IL-1 $\alpha$, and IL-2) in chronic hepatitis C: comparative hybridocytochemical and immunocytochemical study in children and adult patients. J Histochem Cytochem. 2004; 52:29-38

[39] Komminoth P, Werner M. Target and signal amplification: approaches to increase the sensivity of in situ hybridization. Histochem Cell Biol. 1997;108:325-333

[40] Leblond CP, Clermont Y. Spermatogenesis of rat, mouse, hamster and guinea-pig as revealed by the "periodic acidfuchsin sulfurous acid" technique. Am J Anat. 1952;90:167215.

[41] Leblond CP, Clermont Y. Definition of stages of the cycle of the seminiferous epithelium in the rat. Annals of New York Academy of Sciences. 1952;55:548-573.

[42] Clermont Y. Kinetics of spermatogenesis in mammals: seminiferous epithelium cycle and spermatogonial renewal. Physiol Rev. 1972;52:198-236.

[43] Miller DW, Harrison JI, Brown YA, Doyle U, Lindsay A, Adam CL, Lea RG. Immunohistochemical evidence for an endocrine/paracrine role for ghrelin in the reproductive tissues of sheep. Reprod Biol Endocrinol. 2005;3:60-72.

[44] Komarowska H, Wasko R, Iwanik K, Majewski P, Rafinska L, Warenik-Szymankiewicz A, Sowinski J. Ghrelin ovarian cell expression in patients with polycystic ovary syndrome: an immunohistochemical evaluation. Hormone Metab Res. 2006;38:783-788.

[45] Okamoto I, Kawano Y, Murakami D, Sasayama T, Araki N, Miki T, Won AJ, Hideyuki S. Proteolytic release of CD44 intracellular domain and its role in the CD44 signaling pathway. J. Cell Biol. 2001;155:755-762.

[46] Banks WA, Tschop M, Robinson SM, Heiman ML. Extent and direction of ghrelin transport across blood-brain barrier is determined by its unique primary structure. J Pharmacol Exp Therapeutics 2002;302:822-827.

[47] Holst B, Holliday ND, Bach A, Elling CE, Cox HN, Schwartz TW. Common structural basis for constitutive activity of the ghrelin receptor family. J Biol Chem. 2004;279:53806-53817.

[48] Albanesi C, Geremia R, Giorgio M, Dolci S, Sette C, Rossi P. A cell- and developmental stage-specific promoter drives the expression of a truncated c-kit protein during mouse spermatid elongation. Development. 1996;122:1291-1302. 
[49] Mauduit C, Hamamah S, Benahmed M. Stem cell factor/c-kit system in spermatogenesis. Human Reprod. Update 1999;5: 535-545.

[50] Hakovirta H, Yan W, Kaleva M, Zhang F, Vanttinen K, Morris PL, Soder M Parvinen M, Toppari J. Function of stem cell factor as a survival factor of spermatogonia and localization of messenger ribonucleic acid in the rat seminiferous epithelium. Endocrinology 2004;140:1492-1498.

[51] Yan W, Suominen J, Toppari J. Stem cell factor protects germ cells from apoptosis. J Cell Sci. 2000;113:161-168.

[52] Dadoune J-P. New insight into male gametogenesis: what about the spermatogonial stem cell niche? Folia Histochem Cytobiol. 2007;45:141-147.

[53] Panidis D, Goulis DG, Katsikis I, Koliakos G, Georgopoulos NA, Diamanti-Kandarakis E. Serum and seminal plasma ghrelin levels in men with normospermia and dyspermia. Gynecol Endocrinol. 2008;24:320-325.

[54] Kawamura K, Sato N, Fukuda J, Kodama H, Kumagai J, Tanikawa H, Nakamura A, Honda Y, Sato T, Tanaka T. Ghrelin inhibits the development of mouse preimplantation embryo in vitro. Endocrinology. 2003;144:2623-2633.

[55] Holst B, Schwartz TW. Ghrelin receptor mutations - too little height and too much hunger. J Clin Invest. 2006;116:637-641.

[56] Liu G, Fortin J-P, Beinborn M, Kopin AS. Four missense mutations in ghrelin receptor result in distinct pharmacological abnormalities. J Pharmacol Exper Therapeutics. 2007; 322:1036-1043.

[57] Matzuk MM, Lamb DJ. Genetic dissection of mammalian fertility pathways. Nature Medicine 2002;8(suppl. 1):33-40.

[58] Matzuk MM, Lamb DJ. The biology of infertility: research advances in clinical challenges. Nature Medicine. 2008;14: 1197-1213.

[59] Bhat GK, Sea TL, Olantinwo MO, Simorangkir D, Ford GD, Ford BD, Mann DR. Influence of a leptin deficiency on testicular morphology, germ cell apoptosis, and expression lev- els of apoptosis-related genes in the mouse. $J$ Androl. 2006; 27:302-310

[60] Chua SC, Chung WK, Wu-Peng XS, Zhang Y, Liu S, Tartaglia L, Leibel RL. Phenotypes of mouse diabetes and rat fatty due to mutations in the OB (leptin) receptor. Science 1996;271: 994-995.

[61] Giovambattistaa A, Suescuna MO, Nessrallac CCDL, Francac LR, Spinedia E, Calandrab RS. Modulatory effects of leptin on Leydig cell function of normal and hyperleptinemic rats. Neuroendocrinol. 2003;78:270-279.

[62] Lamb D, Whirledge S, Smith R. O-113Ghrelin and leptin interplay in proper gonadal function. Fertility Sterility 2006;86:S48-S48.

[63] Swerdloff RS, Batt RA, Bray GA. Reproductive hormonal function in the genetically obese (ob/ob) mouse. Endocrinology. 1996;98:1359-1364.

[64] Fernandez-Fernandez R, Navaro VM, Barreiro ML, Vigo EM, Tovar S, Sirotkin AV, Casanueva FF, Aguilar E, Dieguez C, Pinilla L, Tena-Sempere M. Effects of chronic hyperghrelinemia on puberty onset and pregnancy outcome in the rat. Endocrinology. 2005;146:3018-3025.

[65] Hamilton C, Scully RE, Kliman B. Hypogonadotropism in Prader-Willi syndrome: induction of puberty and spermatogenesis by clomiphene citrate. Am J Med. 1972;52:322-329.

[66] Eiholzer U, l'Allemand D, Rousson V, Schlumpf M, Gasser T, Girard J, Grüters A, Simoni M. Hypothalamic and gonadal components of hypogonadism in boys with Prader-LabhartWilli syndrome. J Clin Endocrinol MeTable. 2006;91:892898

[67] Jeffcoate WJ, Laurence BM, Edwards CRW, Besser GM. Endocrine function in the Prader-Willi syndrome. Clin Endocrinol. 2007;12:81-89.

Submitted: 25 July, 2009 Accepted after reviews: 4 October, 2009 